\title{
Lipid Profile Variations of the Different ABO Blood Group of Apparently Healthy Subjects in Ekpoma
}

\author{
Airhomwanbor $\mathrm{KO}^{1 *}$, Idehen $\mathrm{IC}^{1}$, Okparaku $\mathrm{SO}^{1}$, Dic-Ijewere $\mathrm{EO}^{2}$, Ehimare $\mathrm{RI}^{2}$, Osarobo \\ $E^{3}$, Omolumen LE ${ }^{1}$, Omosun ER ${ }^{1}$ \\ ${ }^{1}$ Department of Medical Laboratory Sciences, College of Medicine, Ambrose Alli University, Ekpoma, Nigeria \\ ${ }^{2}$ Department of Chemical Pathology, College of Medicine, Ambrose Alli University, Ekpoma, Nigeria \\ ${ }^{3}$ Department of Hematology, College of Medicine, Ambrose Alli University, Ekpoma, Nigeria
}

*Corresponding Author:Airhomwanbor KO, Department of Medical Laboratory Sciences, College of Medicine, Ambrose Alli University, Ekpoma, Nigeria, E-mail: uwaifoha@yahoo.co.uk

Received: 28 November 2018; Accepted: 10 December 2018; Published: 20 December 2018

\begin{abstract}
Dyslipidemia is a recognized major risk factors of cardiovascular diseases, but the impact of the different blood groups has not been extensively investigated; at least in Nigeria where the prevalence is on the increase. This study, therefore assesses serum lipid profile among different ABO blood groups in Ekpoma, Nigeria. The study involved 100 subjects comprising of 25 each of blood groups A and B, 15 and 25 subjects with $\mathrm{AB}$ and $\mathrm{O}$ blood groups respectively. The subjects were male and female within 18-30 years who gave consent and met the inclusion criteria. Following standard procedures blood samples were obtained for serum lipid profile and the results were analyzed using appropriate statistical test (ANOVA) at $\mathrm{p}<0.05$. The results showed that there was no significant difference $(\mathrm{p}>0.05)$ in the serum mean total cholesterol, triglyceride, high density lipoprotein, low density lipoprotein and very low density lipoprotein levels in the different blood groups. However, the AB blood group was more likely to present higher lipid variables. There was significant gender differences in HDL in the A and AB blood groups. Judging by the findings of this study, there is likely no marked effect of blood group on serum lipid profile in apparently healthy individuals.
\end{abstract}

Keywords:Cardiovascular diseases; Dyslipidemia; Lipid profile; ABO blood group;Apparently healthy

\section{Introduction}

The ABO system occurs as a result of polymorphism of complex carbohydrate with different antigenic structures of glycoproteins and glycolipids expressed on the surface of erythrocytes, as glycan units of mucin glycoproteins [1,2]. 
According to Storry, et al.[2], the A and B alleles of the ABO, locus encode A and B glycosyltransferase activities, which convert precursor $\mathrm{H}$ antigen into either $\mathrm{A}$ or $\mathrm{B}$ determinants, the $\mathrm{A}$ and $\mathrm{B}$ antigens having an extra saccharide unit to the $\mathrm{O}$ unit ( $\mathrm{N}$-acetylgalactosamine and galactose, respectively). Group $\mathrm{O}$ individuals lack such transferase enzymes (loss of function) and express basic, unchanged H-antigen [2]. The clinical significance of ABO blood group system is now known to extend beyond blood transfusion and solid organ transplantation to its correlation with pathogenesis of several systemic diseases.

In the past, researches on the association of $\mathrm{ABO}$ blood groups with different pathologies have been of immense interest. Several studies have elucidated the role of blood groups as predisposing factors for diseases such as gastric cancer [3], peptic ulcer [4], pancreatic cancer [5], breast cancer [6], upper urinary tract cancer [7], ovarian cancer [8], bladder cancer [9], pulmonary diseases [10], upper urinary tract infection [11], cardiovascular diseases [12], asthma [13] and psychological disorders [14]. Of these, studies on association of blood groups and cardiovascular diseases (CVD) have been of great significance. Several reports have appeared in recent years, suggesting an association between blood groups and various manifestations of heart diseases [15]. During the last few decades, some reports have suggested that $\mathrm{ABO}$ blood groups are associated with risk of ischemic heart diseases and developing severe manifestation of atherosclerosis [16].

CVD that includes Coronary artery disease (CAD) and other heart diseases are the principal cause of mortality and disability worldwide [17] and lipids and lipoproteins which are central to the metabolism have become increasingly important in the association with coronary heart disease (CHD) [18]. In fact, it has been established that dyslipidemia is one of the major risk factors of cardiovascular diseases and that it acts synergistically with other major risk factors of this disease [19, 20]. Risk factors for developing cardiovascular diseases are known to be proportional to the levels of total serum cholesterol (TC), low-density lipoprotein cholesterol (LDL-C) and triglycerides (TGs). However, there is an inverse relation between risk factors for CVD and levels of serum highdensity lipoprotein cholesterol (HDL-C), since this lipoprotein is known to be protective against heart diseases and stroke by being involved in the reverse cholesterol transport process.

Prior studies show inconsistent results with respect to distribution of ABO blood groups and risk factors for CVD in different parts of the world $[12,15,16]$. Most previous studies have reported that A blood group are predisposed to cardiovascular disease and that type O blood group is a protective anti-atherogenic factors [21, 22]. Nevertheless, the subjects understudy in most of these investigations has been confirmed cases of CVD. Since reducing risk factors is the basic clinical approach to decreasing the mortality and morbidity caused by CVD, we planned to confirm the relationship between $\mathrm{ABO}$ blood group and serum lipid profile among healthy population, with a view to design an effective strategy for primary prevention of risk factors that are known to cause CVD. Also, there is very little data with respect to the relationship between blood pressure, blood grouping and lipid profile in our locality. The aim of this study is therefore to compare the serum lipid profile between the different ABO blood groups and assess the influence of gender in apparently healthy subjects in Ekpoma-Nigeria. 


\section{Materials and Methods}

\subsection{Study area}

This study was carried out in Ekpoma, Esan- West Local Government Area of Edo State. The town is located at latitude $6^{\circ} .75^{\mathrm{I}} \mathrm{N}$ and longitude $6^{\circ} .13^{\mathrm{I}} \mathrm{E}$ with an estimated population size of 125,842 people at the 2006 census [23]. The inhabitants are mainly students, civil servants and farmers.

\subsection{Population of study}

This study was conducted on 100 apparently healthy subjects. The study population consists of 35 blood group O, 25 blood group A, 25 blood group B and 15 blood group AB individuals of age range 18- 30 years. A questionnaire was administered for collection of specific information from each student participating in the study, which was carried out between September and December, 2017.

\subsection{Ethical considerations}

Ethical permission for this study was obtained from the Research and Ethics Committee of Ambrose Alli University, Ekpoma and informed consent was also obtained. The study was conducted according to the protocol approval of the ethical review committees.

\subsection{Inclusion and exclusion criteria}

Only apparently healthy subjects in Ekpoma within the age range 18 and 30 years were recruited for this study. Subjects with pregnancy, DM, history of smoking and any other visible ailments were excluded from this study.

\subsection{Sample collection and analysis}

Two specimen bottles were used for each subject. Anticoagulant bottles containing K2 EDTA for blood grouping test and plain container for lipid profile assay. Fasting blood sample $(5 \mathrm{ml})$ was collected by clean venepuncture from the ante-cubital fossa into already labeled bottles, without undue pressure to either the arm or the plunger of the syringe. The samples in the K2 EDTA anticoagulant bottles were tested immediately for blood group using commercially prepared anti-sera (anti-A, anti-B, anti-AB and anti-D). The blood samples in a plain container were centrifuged at $4000 \mathrm{rpm}$ for 10 minutes. The serum was separated into a clean dry plain container and stored frozen until analysis was done at room temperature.

Total cholesterol was determined via the Enzymatic Endpoint method (CHOD-PAP) following the described method by Richmond [24]. Triglyceride was evaluated via the colorimetric method as described by Trinder [25]. High density lipoproteinwas estimated by the precipitation method described by Lopes-virella [26]. Low density lipoprotein and very low density lipoprotein were estimated using the Friedewaldformular [27]. 


\subsection{Statistical analysis}

The data generated from this study were analyzed using Statistical Package for the Social Sciences (SPSS) version 20 to determine the mean and standard deviation. The level of significance was set at $\alpha=0.05$, and a p-value less than $0.05(\mathrm{P}<0.05)$ was considered statistically significant. The significance of difference among the groups was assessed by repeated-measures analysis of variance (ANOVA) and where applicable student " $t$ " test.

\section{Results}

Table 1 shows the mean serum lipid profile among the different ABO blood group of apparently healthy subjects in Ekpoma. The mean age of the studied groups was between $21.00 \pm 2.82$ years and $22.13 \pm 3.27$ years. There was no significant difference $(\mathrm{F}=0.886 ; \mathrm{p}=0.452 ; \mathrm{p}>0.05)$ in the ages of the blood groups. Mean serum total cholesterol was higher in blood group AB $(3.94 \pm 0.64 \mathrm{mmol} / \mathrm{l})$ but the difference with other blood groups was not significant $(\mathrm{F}=1.703 ; \mathrm{p}=0.172 ; \mathrm{p}>0.05)$. Also, there was a higher mean serum triglyceride level in $\mathrm{AB}$ blood group (1.39 \pm 0.48 $\mathrm{mmol} / \mathrm{l})$ compared to other blood groups but the difference was not significant $(\mathrm{F}=1.206 ; \mathrm{p}=0.312 ; \mathrm{p}>0.05)$. Mean serum high density lipoprotein level was higher in O blood group $(1.80 \pm 0.46 \mathrm{mmol} / \mathrm{l})$, however, the difference was statistically not significant $(\mathrm{F}=0.987 ; \mathrm{p}=0.403 ; \mathrm{p}>0.05)$ compared to other blood groups. Mean serum low density lipoproteins $(1.68 \pm 0.64 \mathrm{mmol} / \mathrm{l})$ and very low density lipoprotein $(0.64 \pm 0.22 \mathrm{mmol} / \mathrm{l})$ were higher in $\mathrm{AB}$ group, but the difference compared to other blood groups were not significant $(\mathrm{p}>0.05)$.

\begin{tabular}{|l|l|l|l|l|l|l|}
\hline Parameters & $\begin{array}{l}\text { Blood group A } \\
(\mathbf{n = 2 5})\end{array}$ & $\begin{array}{l}\text { Blood group B } \\
\mathbf{( n = 2 5 )}\end{array}$ & $\begin{array}{l}\text { Blood group AB } \\
(\mathbf{n = 1 5 )}\end{array}$ & $\begin{array}{l}\text { Blood group O } \\
\mathbf{( n = 3 5 )}\end{array}$ & F-value & p-value \\
\hline AGE (Years) & $21.96 \pm 2.63^{\mathrm{a}}$ & $21.40 \pm 2.48^{\mathrm{a}}$ & $22.13 \pm 3.27^{\mathrm{a}}$ & $21.00 \pm 2.82^{\mathrm{a}}$ & 0.886 & 0.451 \\
\hline TC $(\mathrm{mmol} / \mathrm{l})$ & $3.66 \pm 0.40^{\mathrm{a}}$ & $3.81 \pm 0.53^{\mathrm{a}}$ & $3.94 \pm 0.64^{\mathrm{a}}$ & $3.67 \pm 0.34^{\mathrm{a}}$ & 1.703 & 0.172 \\
\hline TG (mmol/l) & $1.27 \pm 0.32^{\mathrm{a}}$ & $1.33 \pm 0.38^{\mathrm{a}}$ & $1.39 \pm 0.48^{\mathrm{a}}$ & $1.21 \pm 0.26^{\mathrm{a}}$ & 1.206 & 0.312 \\
\hline HDL (mmol/l) & $1.62 \pm 0.31^{\mathrm{a}}$ & $1.73 \pm 0.61^{\mathrm{a}}$ & $1.62 \pm 0.27^{\mathrm{a}}$ & $1.80 \pm 0.46^{\mathrm{a}}$ & 0.987 & 0.403 \\
\hline LDL (mmol/l) & $1.44 \pm 0.33^{\mathrm{a}}$ & $1.50 \pm 0.65^{\mathrm{a}}$ & $1.68 \pm 0.64^{\mathrm{a}}$ & $1.42 \pm 0.38^{\mathrm{a}}$ & $1.813^{\mathrm{a}}$ & 0.167 \\
\hline VLDL $(\mathrm{mmol} / \mathrm{l})$ & $0.58 \pm 0.15^{\mathrm{a}}$ & $0.60 \pm 0.17^{\mathrm{a}}$ & $0.64 \pm 0.22^{\mathrm{a}}$ & $0.55 \pm 0.12^{\mathrm{a}}$ & 1.249 & 0.296 \\
\hline
\end{tabular}

Values are Mean \pm SD. Key: TC-total cholesterol; TG-triglyceride; HDL-high density lipoprotein; LDL-low density lipoprotein; VLDL-very low density lipoprotein.

Table 1: Lipid profile among different ABO blood group of apparently healthy subjects.

Table 2 shows the mean serum lipid profile of blood group A subjects between male and female. Female blood group A had a non-significant higher mean total cholesterol $(3.73 \pm 0.47 \mathrm{mmol} / \mathrm{l}$ vs. $3.60 \pm 0.34 \mathrm{mmol} / \mathrm{l})$ and triglyceride $(1.29 \pm 0.36 \mathrm{mmol} / \mathrm{l}$ vs. $1.26 \pm 0.30 \mathrm{mmol} / \mathrm{l})$ levels and a nonsignificant lower $(\mathrm{p}>0.05)$ low density lipoprotein $(1.31 \pm 0.40 \mathrm{mmol} / 1$ vs. $1.54 \pm 0.23 \mathrm{mmol} / \mathrm{l})$ and very low density lipoprotein $(0.58 \pm 0.17 \mathrm{mmol} / 1 \mathrm{vs}$. $0.57 \pm 0.14 \mathrm{mmol} / \mathrm{l})$ levels compared to male. However, there was a significant higher $(\mathrm{p}<0.05)$ high density 
lipoprotein in the female A blood group (1.79 $\pm 0.18 \mathrm{mmol} / \mathrm{l})$ compared to the male A blood group (1.48 \pm 0.32 $\mathrm{mmol} / \mathrm{l})$.

\begin{tabular}{|l|l|l|l|l|}
\hline Parameters & Female(n=11) & Male(n=14) & t-value & p-value \\
\hline TC $(\mathrm{mmol} / \mathrm{l})$ & $3.73 \pm 0.47$ & $3.60 \pm 0.34$ & 0.822 & 0.419 \\
\hline TG $(\mathrm{mmol} / \mathrm{l})$ & $1.29 \pm 0.36$ & $1.26 \pm 0.30$ & 0.253 & 0.802 \\
\hline HDL $(\mathrm{mmol} / \mathrm{l})$ & $1.79 \pm 0.18$ & $1.48 \pm 0.32^{*}$ & 2.937 & 0.008 \\
\hline LDL $(\mathrm{mmol} / \mathrm{l})$ & $1.31 \pm 0.40$ & $1.54 \pm 0.23$ & 1.845 & 0.078 \\
\hline VLDL $(\mathrm{mmol} / \mathrm{l})$ & $0.58 \pm 0.17$ & $0.57 \pm 0.14$ & 0.229 & 0.821 \\
\hline
\end{tabular}

Values are Mean \pm SD. Key: *indicates significant difference. TC-total cholesterol; TG-triglyceride; HDL-high density lipoprotein; LDL-low density lipoprotein; VLDL-very low density lipoprotein.

Table 2: Lipid profile of male and female blood group A subjects.

Table 3 shows the mean serum lipid profile of blood group B subjects between male and female. Female blood group B subject had non-significant higher mean triglyceride $(1.37 \pm 0.47 \mathrm{mmol} / 1 \mathrm{vs} .1 .29 \pm 0.29 \mathrm{mmol} / \mathrm{l})$ and very low density lipoprotein $(0.62 \pm 0.21 \mathrm{mmol} / 1$ vs. $0.59 \pm 0.13 \mathrm{mmol} / \mathrm{l})$ levels while male counterpart had non-significant higher mean total cholesterol level $(3.72 \pm 0.56 \mathrm{mmol} / 1$ vs. $3.89 \pm 0.50 \mathrm{mmol} / \mathrm{l})$. However, female blood group B subjects had significantly $(\mathrm{p}<0.05)$ high mean high density lipoprotein $(1.99 \pm 0.72 \mathrm{mmol} / 1 \mathrm{vs} .1 .49 \pm 0.35 \mathrm{mmol} / \mathrm{l})$ while male had significant higher $(\mathrm{p}<0.05)$ mean low density lipoprotein $(1.20 \pm 0.48$ vs. $1.77 \pm 0.69)$.

\begin{tabular}{|l|l|l|l|l|}
\hline Parameters & Female(n=12) & Male(n=13) & t-value & p-value \\
\hline TC $(\mathrm{mmol} / \mathrm{l})$ & $3.72 \pm 0.56$ & $3.89 \pm 0.50$ & 0.808 & 0.427 \\
\hline TG $(\mathrm{mmol} / \mathrm{l})$ & $1.37 \pm 0.47$ & $1.29 \pm 0.29$ & 0.538 & 0.596 \\
\hline HDL $(\mathrm{mmol} / \mathrm{l})$ & $1.99 \pm 0.72$ & $1.49 \pm 0.35^{*}$ & 2.223 & 0.036 \\
\hline LDL $(\mathrm{mmol} / \mathrm{l})$ & $1.20 \pm 0.48$ & $1.77 \pm 0.69^{*}$ & 2.415 & 0.024 \\
\hline VLDL $(\mathrm{mmol} / \mathrm{l})$ & $0.62 \pm 0.21$ & $0.59 \pm 0.13$ & 0.503 & 0.620 \\
\hline
\end{tabular}

Values are Mean \pm SD. Key: *indicates significant difference. TC-total cholesterol; TG-triglyceride; HDL-high density lipoprotein; LDL-low density lipoprotein; VLDL-very low density lipoprotein.

Table 3: Lipid profile of apparently healthy male and female blood group B subjects.

Table 4 shows the mean serum lipid profile of blood group $\mathrm{AB}$ subjects between male and female. Female blood group AB subjects had non-significant higher $(\mathrm{p}>0.05)$ mean total cholesterol $(3.99 \pm 0.65 \mathrm{mmol} / 1$ vs. $3.88 \pm 0.67$ $\mathrm{mmol} / \mathrm{l})$ and low density lipoprotein $(1.84 \pm 0.61 \mathrm{mmol} / \mathrm{l} \mathrm{vs} .1 .50 \pm 0.69 \mathrm{mmol} / \mathrm{l})$ while the male counterpart had nonsignificant higher ( $>0.05)$ mean triglyceride $(1.37 \pm 0.39 \mathrm{mmol} / 1$ vs. $1.41 \pm 0.59 \mathrm{mmol} / \mathrm{l})$, high density lipoprotein 
$(1.52 \pm 0.21 \mathrm{mmol} / 1$ vs. $1.74 \pm 0.29 \mathrm{mmol} / \mathrm{l})$ and very low density lipoprotein $(0.63 \pm 0.19 \mathrm{mmol} / \mathrm{l}$ vs. $0.64 \pm 0.27$ $\mathrm{mmol} / \mathrm{l})$.

\begin{tabular}{|l|l|l|l|l|}
\hline Parameters & Female(n=8) & Male(n=7) & t-value & p-value \\
\hline TC $(\mathrm{mmol} / \mathrm{l})$ & $3.99 \pm 0.65$ & $3.88 \pm 0.67$ & 0.336 & 0.742 \\
\hline TG $(\mathrm{mmol} / \mathrm{l})$ & $1.37 \pm 0.39$ & $1.41 \pm 0.59$ & 0.150 & 0.883 \\
\hline HDL $(\mathrm{mmol} / \mathrm{l})$ & $1.52 \pm 0.21$ & $1.74 \pm 0.29$ & 1.680 & 0.117 \\
\hline LDL $(\mathrm{mmol} / \mathrm{l})$ & $1.84 \pm 0.61$ & $1.50 \pm 0.69$ & 1.020 & 0.326 \\
\hline VLDL (mmol/l) & $0.63 \pm 0.19$ & $0.64 \pm 0.27$ & 0.085 & 0.934 \\
\hline
\end{tabular}

Values are Mean \pm SD. Key: TC-total cholesterol; TG-triglyceride; HDL-high density lipoprotein; LDL-low density lipoprotein; VLDL-very low density lipoprotein.

Table 4: Lipid profile of apparently healthy male and female blood group AB subjects.

Table 5 shows the mean serum lipid profile of blood group $\mathrm{O}$ subjects between male and female. Except for the mean low density lipoprotein $(1.35 \pm 0.40 \mathrm{mmol} / 1$ vs. $1.28 \pm 0.36 \mathrm{mmol} / \mathrm{l})$ that was non-significantly higher $(\mathrm{p}>0.05)$ in female blood group $\mathrm{O}$ subjects, mean total cholesterol $(3.58 \pm 0.30 \mathrm{mmol} / 1 \mathrm{vs}$. $3.77 \pm 0.36 \mathrm{mmol} / \mathrm{l})$, triglyceride $(1.16 \pm 0.15 \mathrm{mmol} / 1$ vs. $1.25 \pm 0.33 \mathrm{mmol} / \mathrm{l})$, high density lipoprotein $(1.68 \pm 0.43 \mathrm{mmol} / \mathrm{l} \mathrm{vs} .1 .92 \pm 0.47 \mathrm{mmol} / \mathrm{l})$ and very low density lipoprotein $(0.53 \pm 0.07 \mathrm{mmol} / 1$ vs. $0.57 \pm 0.15 \mathrm{mmol} / \mathrm{l})$ were non-significantly higher $(\mathrm{p}>0.05)$ in male blood group $\mathrm{O}$ subjects.

\begin{tabular}{|l|l|l|l|l|}
\hline Parameters & Female(n=18) & Male(n=17) & t-value & p-value \\
\hline TC $(\mathrm{mmol} / \mathrm{l})$ & $3.58 \pm 0.30$ & $3.77 \pm 0.36$ & 1.690 & 0.100 \\
\hline TG $(\mathrm{mmol} / \mathrm{l})$ & $1.16 \pm 0.15$ & $1.25 \pm 0.33$ & 1.036 & 0.308 \\
\hline HDL $(\mathrm{mmol} / \mathrm{l})$ & $1.68 \pm 0.43$ & $1.92 \pm 0.47$ & 1.536 & 0.134 \\
\hline LDL $(\mathrm{mmol} / \mathrm{l})$ & $1.35 \pm 0.40$ & $1.28 \pm 0.36$ & 0.573 & 0.571 \\
\hline VLDL $(\mathrm{mmol} / \mathrm{l})$ & $0.53 \pm 0.07$ & $0.57 \pm 0.15$ & 1.050 & 0.301 \\
\hline
\end{tabular}

Values are Mean \pm SD. Key: TC-total cholesterol; TG-triglyceride; HDL-high density lipoprotein; LDL-low density lipoprotein; VLDL-very low density lipoprotein.

Table 5: Lipid profile of apparently healthy male and female blood group O subjects.

\section{Discussion}

Risk factors for developing cardiovascular diseases are known to be proportional to the levels of total serum cholesterol (TC), low-density lipoprotein cholesterol (LDL-C) and triglycerides (TGs) [19, 20]. This study assessed serum lipid profile among the different ABO blood group of apparently healthy subjects in Ekpoma to know which blood group is likely to be more exposed to cardiovascular diseases. The findings of the present study showed that 
there was no significant association in the serum levels of TC, TG and lipoproteins among the different blood groups. These observations are in agreement with the findings by Amirzadegan et al. [28] who also showed no positive correlation between different blood groups and development of CAD and the prevalence of major cardiovascular risk factors in patients who underwent coronary artery bypass graft. Studies by Ghazaee et al. [29] and Farah et al. [30] have also revealed a lack of association between ABO blood groups and serum lipid profile among Iranian and Saudi Arabian population respectively. In fact, Contiero et al. [31] working in Italian population revealed there was no association between total, HDL- and LDL-cholesterol and ABO blood groups while triglyceride levels were higher in individuals with $\mathrm{B}$ antigen $(\mathrm{B}+\mathrm{AB})$ than in subjects without this antigen. The findings of this study disagree with that of Theanacho et al. [32] working within Aba Metropolitan who found the tendency of blood group A individual to be more likely predisposed to cardiovascular disease genetically than individuals with blood $\mathrm{O}$.

Hypercholesterolemia is considered a risk factor in the development of ischemic heart disease [33]. Besides, elevated low density lipoprotein cholesterol, depressed high density lipoprotein cholesterol as well as increase triglyceride are other important risk factors for cardiovascular diseases [34] and this relation holds true irrespective of sex and age. Although not significant in the present study, it was observed that blood group AB subjects have higher levels of total cholesterol, triglyceride and low density lipoprotein when compared with other blood groups. Also lower level of high density lipoprotein was also recorded in blood group AB. Thus, suggesting blood group AB to me more likely exposed. This result is in agreement with the findings of Meade et al. [16] where they showed higher incidence of ischemic heart diseases in patients with blood group phenotype $\mathrm{AB}$ as compared with groups $\mathrm{O}$, A or B. Similar findings have been reported by Girgla et al. [35] and Farah et al. [30] where they showed a significant relation of phenotype $\mathrm{AB}$ with serum lipid parameters in north Indian population and Saudi Arabian respectively. Since high levels of serum cholesterol and low high density lipoprotein cholesterol are known to be major risk factors in the development of CVD, these results indicate that people with blood group $\mathrm{AB}$ may be at a higher risk of developing these diseases.

There was no significant association in the serum lipid profile of studying population based on gender except in blood group A and B where there were significant increases in the levels of high density lipoprotein in female subjects when compared with their male counterpart. The increase may be as a result of high levels of circulating oestrogen in the female participants. This assertion is based on the fact by Knopp et al. [36] that estrogen exerts a favorable effect on lipoprotein metabolism by increasing VLDL-C synthesis leading to a subsequent decrease in LDL-C and increase in HDL-C. Thus, the observed significance present in the blood group A and B female compared to their male counterpart may be hormone related.

In conclusion, this study revealed that there was no marked relationship between serum lipid values and different ABO blood groups in the study population. Since lipid profile is a genetic component, family history may play an important role in the development of risk factors for cardiovascular diseases. Based on the blood group showing abnormal levels of lipid parameters, the study implicated blood group AB. It is however important to know that 
many factors play a major role to produce clinical cardiovascular diseases. It is our opinion that other factors like environmental factors might be a likely predisposing factor that the $\mathrm{ABO}$ blood type in stimulation of cardiovascular diseases. It our concluded therefore that more elaborate study with a much larger sample size be carried out to confirm the findings, especially association of blood group $\mathrm{AB}$ and Rhesus with lipid profile.

\section{References}

1. Eastlund T. The histo-blood group ABO system and tissue transplantation. Transfusion 38 (1998): 975-988.

2. Storry JR, Olsson ML. The ABO blood group system revisited: A review and update. Immunohematology 25 (2009): 48-59.

3. Wang Z, Liu L, Ji j, et al. ABO Blood Group System and Gastric Cancer: A Case-Control Study and MetaAnalysis. Int J Mol Sci 13 (2012): 13308-13321.

4. Edgren G, Hjalgrim H, Rostgaard K, et al. Risk of gastric cancer and peptic ulcers in relation to ABO blood type: A cohort study. Am J Epidemiol 172 (2010): 1280-1285.

5. Risch HA, Lu L, Wang J, et al. ABO Blood Group and Risk of Pancreatic Cancer: A Study in Shanghai and Meta-Analysis. Am J Epidemiol177 (2013): 1326-1337.

6. Flavarjani AHM, Hedayatpour B, Bashardoost N, et al. Study of the association between blood types and breast cancer among Isfahanian women with breast cancer. Adv Biomed Res 43 (2014): 1-10.

7. Kvist E, Lauritzen AF, Bredesen J, et al. Relationship Between Blood Groups and Tumors of the Upper Urinary Tract. Scandinavian Journal of Urology and Nephrology 22 (1988): 289-291.

8. Gates MA, Wolpin BM, Cramer DW, Hankinson SE, et al. ABO blood group and incidence of epithelial ovarian cancer. Int J Cancer 128 (2011): 482-486.

9. Nakata S, Sato J, Ohtake N, et al. Epidemiological study of risk factors for bladder cancer. HinyokikaKiyo (Article in Japanese) 41 (1995): 969-977.

10. Kauffmann F, Frette C, Pham QT, et al. Associations of blood group-related antigens to FEV1, wheezing and asthma. Am J Respir Crit Care Med 153 (1996): 76-82.

11. Voigtmann B,Burchardt U. ABO blood groups in patients with nephropathies (German). Z Gesamte Inn Med 46 (1991): 156-159.

12. Capuzzo E, Bonfanti C, Frattini F, et al. The relationship between ABO blood group and cardiovascular disease: results from the Cardio risk program. Ann Transl Med 4 (2016): 189-193.

13. Falsarella N, Ferreira AIC, Nakashima F, et al. Evidence of an association between the O blood group and allergic rhinitis. Rev Bras HematolHemoter 33 (2011): 444-448.

14. Abakah HSS. Depression and Its Relation with Blood Group According Differences (Sex).International Journal of Applied Science and Technology 5 (2015): 175-184.

15. McKeigue PM. Coronary heart disease in Indians, Pakistanis, and Bangladeshis: Aetiology and possibilities for prevention. Br Heart J 67 (1992): 341-342.

16. Meade TW, Cooper JA, Stirling Y, et al. Factor VIII, ABO blood group and the incidence of ischemic heart disease. British Journal of Hematology 88 (1994): 601-607. 
17. Mendis S, Puska P, Norrving B. Global Atlas on Cardiovascular Diseases Prevention and Control. World Health Organization Geneva $2011: 3-18$.

18. Hevonoja KL, Chait MH, Howard NT. Metabolism of low density lipoprotein from patients with diabetic hyperglyceridemia by cultured human skin fibroblasts. Diabetes 34 (2000): 8-14.

19. Hatmi ZN, Tahvildari S,Gafarzadeh MA, et al. Prevalence of coronary artery disease risk factors in Iran: A population based survey. BMC Cardiovascular Disorders 32 (2007): 1-5.

20. Klop B, Elte JW,Cabezas MC. Dyslipidemia in obesity: mechanisms and potential targets. Nutrients 5 (2013): 1218-1240.

21. Platt D, Mulhberg W, Kiehl L, et al.ABO blood group system, age, sex and risk factors and cardiac infarction. ArchGerontol Geritar 4 (2000): 241-249.

22. Stakisaitis D, Masuylis A, Benetitis R. Coronary artherosclerosis and blood groups of ABO system in women. Kaunas 38 (2000): 230-235.

23. Ogbeide EM,Ikpotokin O. Population Model of Esan West Local Government Area of Edo State, Nigeria. Researcher 2 (2010): 9.

24. Richmond W.The development of an enzymatic technique for the assay of cholesterol in biological fluid. Scan J Clin Lab Invest 29 (1972): 26-26.

25. Trinder P. Cholesterol and Triglycerides estimation. Ann ClinBiochem 6 (1969): 24-26.

26. Lopes-Virella MF.High-Density Lipoprotein estimation, Precipitation method. Clin Chem 18 (1972):449.

27. Friedewald WT, Levy RI, Fredrickson DS.Estimation of the concentration of LDL-Cholesterol in plasma without use of the preparative ultracentrifuge. Clin Chem 18 (1972): 508-899.

28. Amirzadegan A, Salarifar M, Sadeghian S, et al. Correlation between ABO blood groups, major risk factors, and coronary artery disease. Int J Cardiol 110 (2006): 256-258.

29. Ghazaee SP, Bakhshandeh H, Mehrzad N, et al. ABO/Rh blood groups distribution and serum lipid profile: Is there any association? Health MED 8 (2014): 194-198.

30. Farah A, Rana Z, Rahma K. Relationship of blood groups with risk factors for cardiovascular diseases in saudiarabian population. Asian Journal of Research in Biological and Pharmaceutical Sciences 5 (2017): 16-24.

31. Contiero E, Chinello GE, Folin M. Serum lipids and lipoproteins associations with ABO blood groups. Anthropol Anz 52 (1994): 221-230.

32. Iheanacho K, Offiah S, Udo M, et al. Evaluation of Lipid Profile of Different ABO Blood Groups. International Journal of Research Studies in Medical and Health Sciences 3 (2018): 13-14.

33. Wafi NA. Blood groups and serum cholesterol. Kurdistan Academician Journal 5 (2007): 35-39.

34. Grover SA, Coupal L, Xiao PH. Identifying adults at increased risk of coronary disease.Journal of American Medical Association 274 (1995): 801-806.

35. Girgla KK, Kaur J, Kiran BK. Study of Serum Cholesterol and Lipoproteins in relation to ABO Blood Groups in North Indian Population.Indian Journal of Fundamental an Applied Life Sciences 1 (2011): 6872.

36. Knopp RH, Paramsothy P, Retzlaff BM, et al. Sex differences in lipoprotein metabolism and dietary 
response: basis in hormonal differences and implications for cardiovascular disease.Curr Cardiol Rep 8 (2006): 452-459.

Citation:Airhomwanbor KO, Idehen IC, OKPARAKU SO, Dic-Ijewere EO, Ehimare RI, Osarobo E, Omolumen LE, Omosun ER. Lipid Profile Variations of the Different ABO Blood Group of Apparently Healthy Subjects in Ekpoma. Archives of Internal Medicine Research 1 (2018): 006-015.

(c) (P) $\begin{aligned} & \text { This article is an open access article distributed under the terms and conditions of the } \\ & \text { Creative Commons Attribution (CC-BY) license } 4.0\end{aligned}$ 